\title{
First pre-modern record of the gyrfalcon (Falco rusticolus) in north-east Greenland
}

\author{
Gina E. Moseley ${ }^{1}$, Jørgen Rosvold² ${ }^{2}$ Anne Birgitte Gotfredsen³ ${ }^{3}$ Irka Hajdas $^{4}$, Olivier Gilg5,6, \\ Kristian M. Gregersen ${ }^{7}$, Christoph Spötl ${ }^{1}$ \& R. Lawrence Edwards ${ }^{8}$ \\ ${ }^{1}$ Institute of Geology, University of Innsbruck, Innsbruck, Austria; \\ ${ }^{2}$ Department of Terrestrial Biodiversity, Norwegian Institute for Nature Research, Trondheim, Norway; \\ ${ }^{3}$ Globe Institute, University of Copenhagen, Copenhagen, Denmark; \\ ${ }^{4}$ Laboratory of Ion Bean Physics, Zurich, Switzerland; \\ ${ }^{5}$ Chrono-environment Lab, Université de Franche-Comté, France; \\ ${ }^{6}$ Groupe de Recherche en Écologie Arctique, Francheville, France; \\ ${ }^{7}$ Department of Biology, Natural History Museum of Denmark, Copenhagen, Denmark; \\ ${ }^{8}$ School of Earth Sciences, University of Minnesota, Minneapolis, MN, USA
}

\begin{abstract}
Gyrfalcon (Falco rusticolus) is the largest falcon in the world. It inhabits a wide range of climate zones in the Northern Hemisphere, from boreal forests in the south of its range to the arid polar deserts of the High Arctic. In Greenland, because of the harsh, remote environments in which gyrfalcons live, research related to the contemporary and pre-modern periods has been limited to the north-west, central west and central east coasts, with no specific investigations being conducted for the north-east. Here, we report the first pre-modern record of a gyrfalcon in north-east Greenland, located at $80.4^{\circ} \mathrm{N}$ in Kronprins Christian Land. Skin tissue from a decaying gyrfalcon's body was radiocarbon dated to 769-944 CE (common era) using a terrestrial-only calibration curve, and 1 182-1456 CE using a marine-only calibration curve. Since the gyrfalcon has a mixed terrestrial/marine diet, the actual age can be said to belong between these two groups. This limited data, therefore places the presence of the gyrfalcon in north-east Greenland during a period of prolonged elevated temperatures and climate stress associated with the Medieval Climate Anomaly. Whether the gyrfalcon was part of a larger population or a straggler, and whether the species survived the whole of the Medieval Climate Anomaly in north-east Greenland, is unknown.
\end{abstract}

\section{Introduction}

The largest of the falcon species, the gyrfalcon (Falco rusticolus), has an extensive geographic distribution ranging from the High Arctic to the boreal forests of Canada, Russia and northern Europe (Potapov \& Sale 2005; Johnson et al. 2007; Avibirds 2012). The High-Arctic regions are characterized by cold, dry, harsh environments in remote locations, which has hampered extensive research related to the gyrfalcon in this particular environment. Of the little research that has been conducted, the most studied Greenlandic populations are found in the northwest (Thule), central west (Kangerlussuaq) and central east (Scoresbysund) (Johnson et al. 2007; Burnham et al. 2009; Burnham \& Newton 201 1), whereas, to our knowledge, no specific research has been conducted on the gyrfalcon in north-east Greenland. At present, concern for the future of the gyrfalcon is growing as climate change threatens its existence by restricting its food source and increasing competition from the more aggressive peregrine falcon (Falco peregrinus; Johnson et al. 2007; Burnham \& Burnham 2011) and raven (Corvus corax; Sokolov et al. 2017).

Here, we present the first pre-modern evidence of a gyrfalcon in north-east Greenland following a chance discovery in August 2015. 

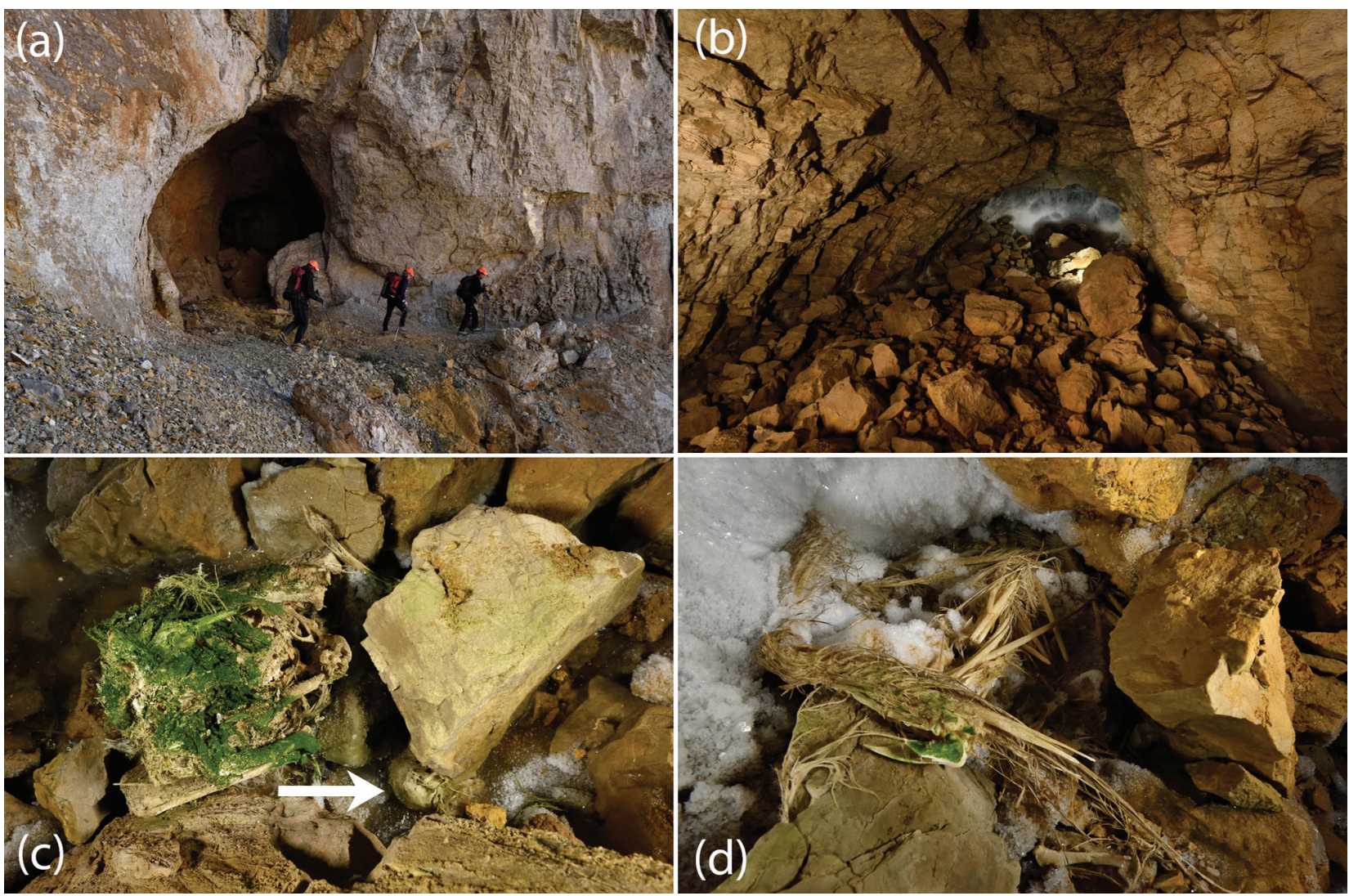

Fig. 1 (a) The entrance to the cave. (b) The rear of the cave, where the bird remains were found. (c) The remains of a bird torso, covered in what appeared to be green moss or mould, lying on the floor. The skull is embedded in ice underneath the bottom corner of the large rock to the right of the torso, as indicated by the arrow. (d) Wings and feathers in the hoar frost on the wall of the cave.

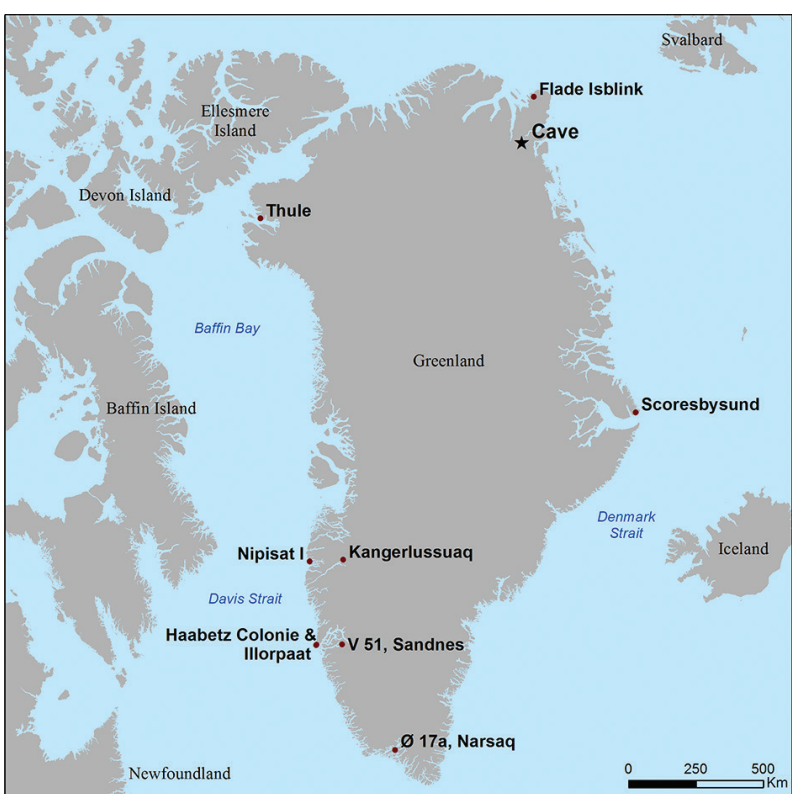

Fig. 2 Location of the cave site used in this study, as well as other places mentioned in the text.

\section{Methods}

\section{Site}

The remains of a bird were discovered embedded in ice (Fig. 1) at the back of a cave (location: $80.3772^{\circ} \mathrm{N}$, $-21.7476^{\circ} \mathrm{W}$ ) in Kronprins Christian Land, north-east Greenland (Fig. 2). The cave is formed in OrdovicianSilurian limestone and is located at an elevation of $510 \mathrm{~m}$ a.s.l., on the west wall of a 1-km-long north-south tributary valley of the larger Grottedalen valley. The cave is ca. $15 \mathrm{~m}$ in length and contains a $90^{\circ}$ left-hand bend ca. $8 \mathrm{~m}$ from the entrance. The entrance is located in a cliff and measures ca. $6 \mathrm{~m}$ wide by ca. $5 \mathrm{~m}$ high, whilst the rear of the cave measures ca. $2 \mathrm{~m}$ wide by ca. $1 \mathrm{~m}$ high. The temperature at the rear of the cave was recorded as $2.8^{\circ} \mathrm{C}$ on 5 August 2015, using a Kestrel 4500 pocket weather meter. The nearest meteorological station is situated near the coast, ca. $205 \mathrm{~km}$ to the north-east at Station Nord $\left(81.605^{\circ} \mathrm{N},-16.684^{\circ} \mathrm{W}\right)$. The climate at the cave site is however expected to be more continental with warmer summers and colder winters than at Station Nord (Krinsley 
1960; Bennike \& Weidick 2001). Limited meteorological measurements taken in the vicinity of the cave show the region to be semi-arid $(<150 \mathrm{~mm}$ precipitation per year; Krinsley 1960). In 1960, daily air temperature reached highs of $5^{\circ} \mathrm{C}$ in May, $13^{\circ} \mathrm{C}$ in June and $14^{\circ} \mathrm{C}$ in July (Krinsley 1960). The cave is located ca. $45 \mathrm{~km}$ from marine water.

Bird remains were found in two separate parts of the cave: a torso, spine and skull were embedded in ice on the floor (Fig. 1c), and wings and feathers were found ca. $0.5 \mathrm{~m}$ away in the hoar frost on the wall (Fig. 1d). It is assumed that both finds belong to the same individual, but extensive investigations have not been conducted. Both remains were covered in what appeared to be green moss or mould. The remains smelled when prodded. Bones with attached skin tissue were collected from the remains in the floor for radiocarbon dating, whilst a feather and a loose tangle of down and small feathers were collected from the remains in the wall for use in identification (Fig. 3). The bone and feather are archived at the Natural History Museum of Denmark, University of Copenhagen, with collection numbers Z.M.K. 54/2017 for the Natural History Museum of Denmark and KNK 3916 for the National Museum of Greenland.

\section{Identification methods}

Because of the limited amount of material, and difficulty in obtaining more, destructive identification methods were kept to a minimum.

A dichotomous key for identifying major skeletal elements of the bird, encompassing metrics and morphological diagnostic criteria (Bocheński \& Tomek 2009), was used to narrow the number of possible avian orders for specimen KNK 3916. The general appearance of the bones and feathers indicated early on that the specimen was raptorial, so the feather and bones were compared to modern medium-large raptorial Palaearctic and Nearctic species that have black and white feathers. This included the peregrine falcon, gyrfalcon, goshawk (Accipiter gentilis) and snowy owl (Bubo scandiacus). The cross-examination was undertaken relative to the reference collection at the Natural History Museum of Denmark and morphological characteristics described by Otto (1981). Additionally, downy (plumulaceous) feather barbs were sampled for identification by microscopic examination (Dove $\&$ Koch 2010). Microslides were prepared from one downy barb of the large feather and from several samples from the loose tangle of small
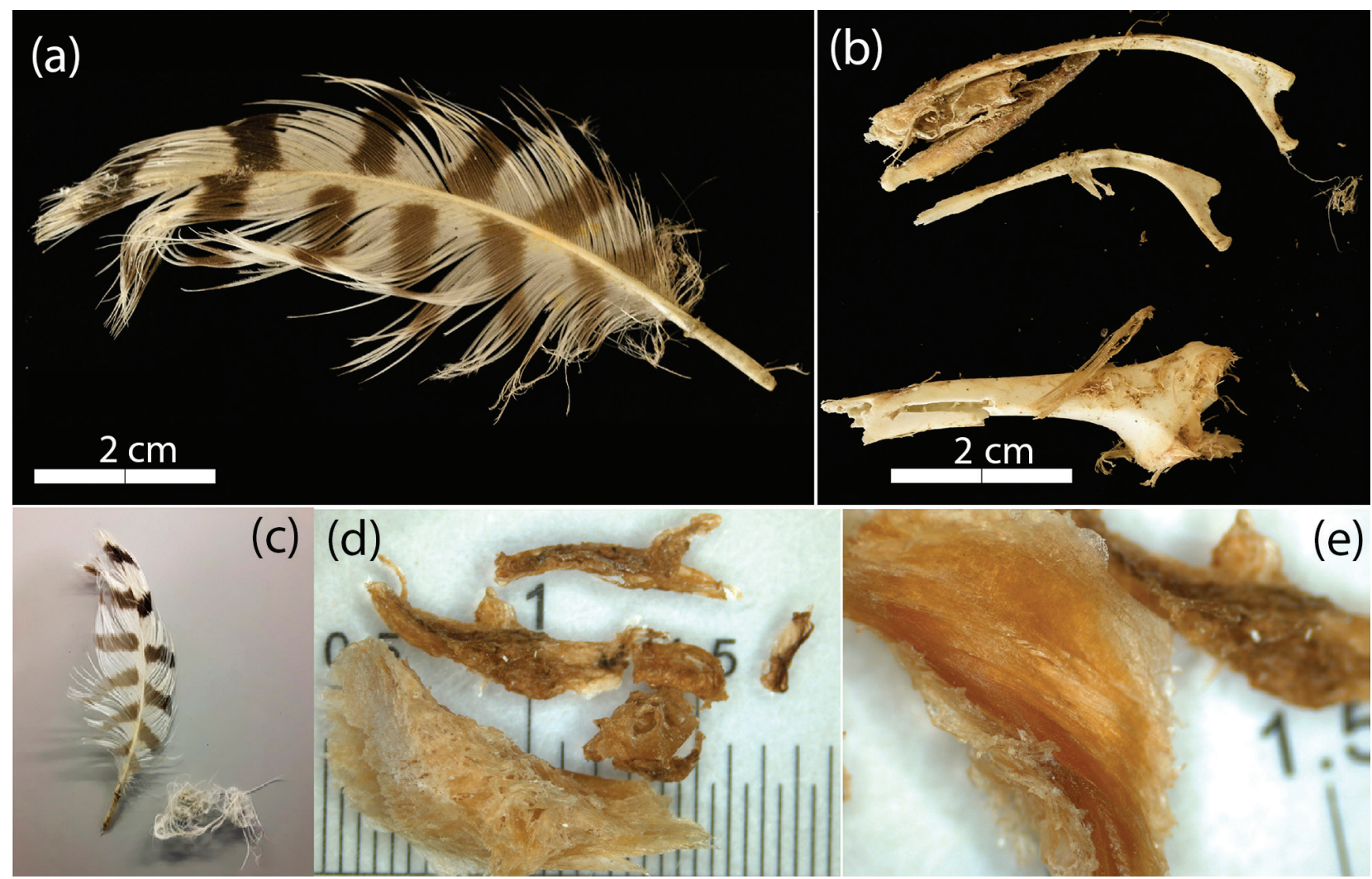

Fig. 3 (a) Feather collected for identification. (b) Bones collected for radiocarbon dating upon which skin tissue was found. (c) Feather and tangle of down and small feathers. (d-e) Skin and tissue found on the bones. 
feathers. Microscopic examination of sizes, shapes and pigmentation patterns of barbules on downy barbs reveals diagnostic characteristics that are specific to various taxonomic levels of birds and can be used to identify at least the family (Chandler 1916; Brom 1986; Dove 8 Koch 2010). The microslides were investigated using a Leica light microscope at 100-400× magnification and compared to a large library of reference samples at the Norwegian University of Science and Technology University Museum. Photographs were taken with a Euromex CMEX-18Pro microscope camera using the ImageFocusAlpha software.

\section{Radiocarbon dating}

The bone sample (GD-20-2-Bone) was examined and cleaned in an ultra-sonic bath of distilled water for $15 \mathrm{~min}$. Fragments of tissue (skin) were detected on the bone and picked for analysis. A piece of the skin and a fragment of the bone were checked for the $\mathrm{C} / \mathrm{N}$ atomic mass ratio yielding values of 3.15 and 3.26, respectively. Only the tissue was analysed further (laboratory code ETH-64502). It underwent a treatment of acid-base-acid washes (Hajdas 2008) to remove potential contamination of carbonates and humic acids. The dry, clean tissue weighing 2.7 $\mathrm{mg}$, which is equivalent to $1 \mathrm{mg}$ of carbon, was weighed into tin cups for combustion in the Elemental Analyser and subsequent graphitization (Wacker et al. 2010). The resulting graphite was pressed into aluminium cathodes and the ${ }^{14} \mathrm{C} /{ }^{12} \mathrm{C}$ and ${ }^{13} \mathrm{C} /{ }^{12} \mathrm{C}$ ratios were measured using the Mini Carbon Dating System dedicated accelerator mass spectrometry facility of ETH Zurich (Synal et al. 2007). The radiocarbon age was calculated following the method described by Stuiver \& Polach (1977) using the measured ${ }^{14} \mathrm{C}$ content after correction for standards, blank values and fractionation $\left(\delta^{13} \mathrm{C}\right.$ values were measured semi-simultaneously on graphite). The reported conventional age in years BP (before $1950 \mathrm{CE}$ ) was calibrated to a calendar age using OxCal version 4.2.4 (Ramsey \& Lee 2013) and the IntCall3 atmospheric curve (Reimer et al. 2013) as well as the Marinel3 curve (Reimer et al. 2013).

\section{Results}

\section{Identification}

Different lines of evidence were used to narrow down the pool of potential candidates. In the first instance, the shape and stiffness of the feather indicate that it originates from the lower arm (secondaries area) above the secondary coverts. Comparison of the cave feather with that of the male and female snowy owls and gyrfalcon feathers of different ages revealed that the feather most likely belonged to a gyrfalcon (Fig. 4). Elimination of the snowy owl from the

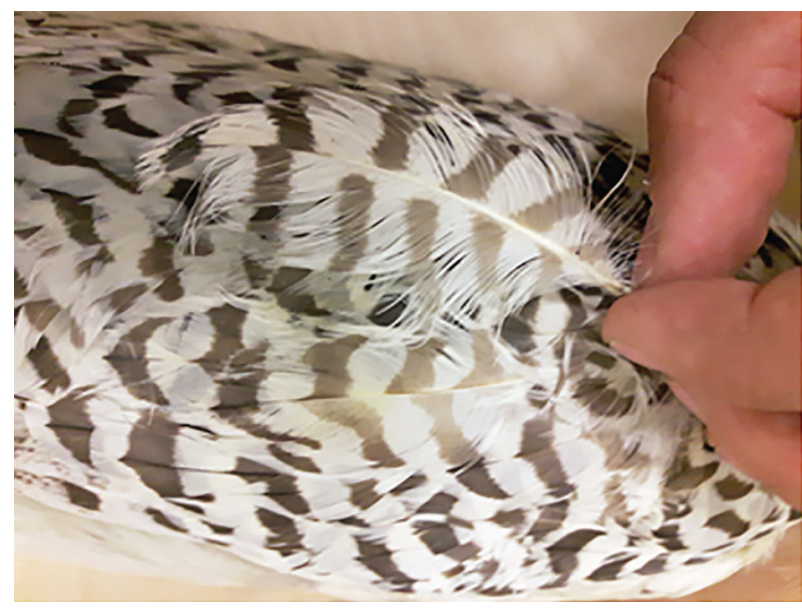

Fig. 4 The large feather collected in this study shown over the wing of a Greenland gyrfalcon.

candidate pool was further confirmed through microscopic analysis of the downy feather barbs (Fig. 5). Both falcons and owls have long thin barbules with pigmented nodes all along their length, with long distances between nodes. These taxa differ in that falcons have small, expanded nodes all along the barbule, while owls have one to three widely expanded proximal nodes and almost non-distinct nodes located distally (Brom 1986; Dove \& Koch 2010). KNK 3916 is similar to reference samples of gyrfalcon in overall barb shape, as well as pigmentation pattern in barbules, node shape and distance between nodes.

Examination of the recovered bone (proximal part of a left scapula) in comparison to scapulae of similar sized raptors showed that KNK 3916 differed morphologically from Accipitridae and Strigiformes. In particular, the dichotomous key of Bocheński and Tomek (2009) showed that the KNK 3916 scapula conforms to: state 1, with a maximum articular length of between 9.00 and $35.0 \mathrm{~mm}$; state 2, where the facies articularis humeralis is elongated, with its longer axis approximately aligned with the long axis of the shaft; state 7 , with a maximum articular length between 11.0 and $27.0 \mathrm{~mm}$ and finally; state $8^{\prime}(\mathrm{a})$, where the acromion forms only one apex, or $8^{\prime}(b)$, where there are two apexes with the lateral apex reaching further cranially than the medial apex. The specimen KNK 3916 clearly has one broad apex indicating it belongs to state $8^{\prime}(a)$, hence separating it from Strigiformes and most other raptors including Accipitridae that conform to state $8^{\prime}$ (b) (Bocheński \& Tomek 2009). In addition, seen from a cranial view, the scapula of Accipitridae has a curved acromion whereas the acromion of the KNK 3916 has a plump, broad rectangular shape indicating it belongs to the genus Falco. Accipitridae and Strigiformes were thus eliminated from the candidate species and the 

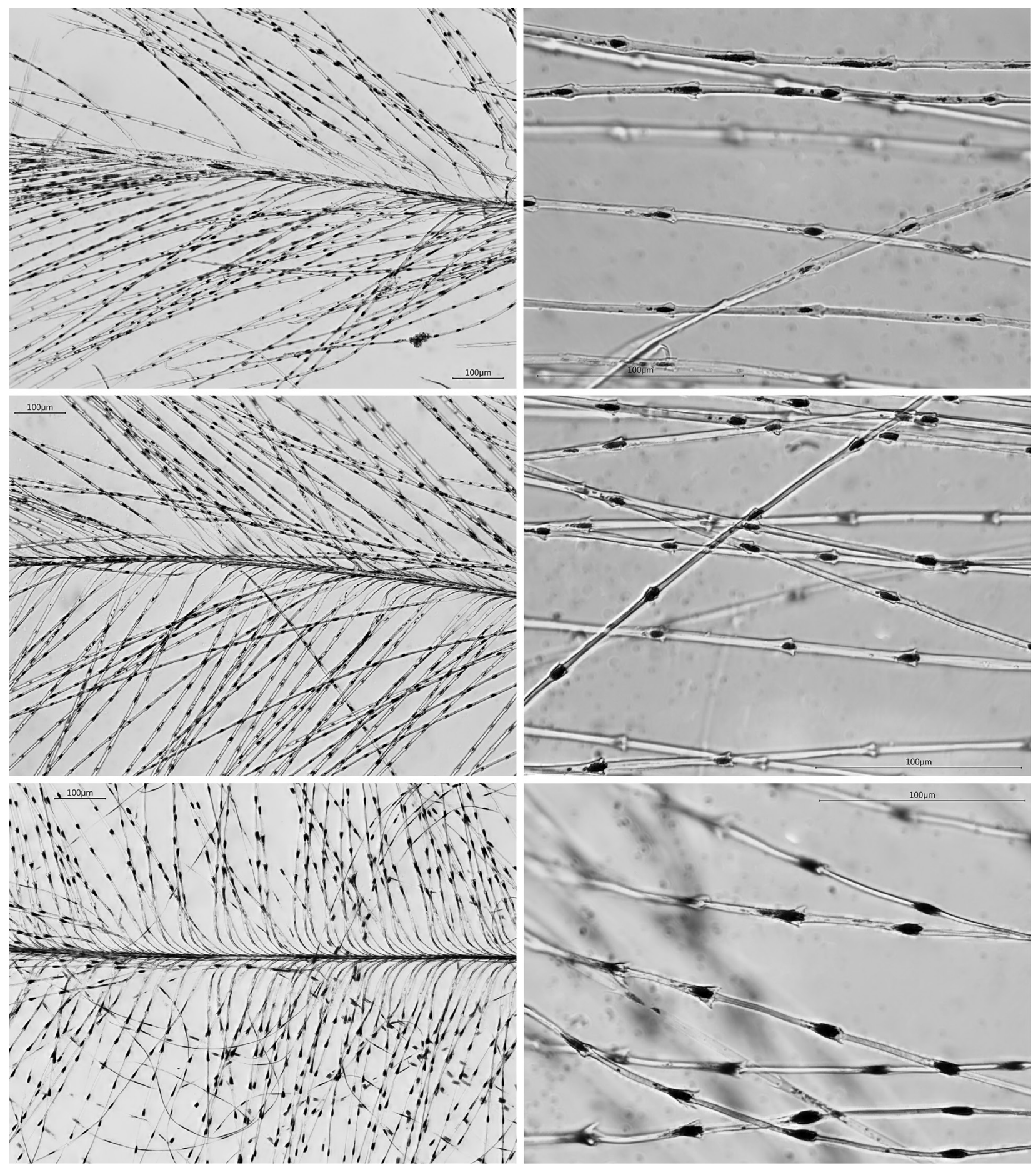

Fig. 5 Microscope images of downy barbs (left) and barbules (right) of feather samples from the cave find (top), reference gyrfalcon (middle) and reference snowy owl (bottom). Scale bars are $100 \mu \mathrm{m}$.

Arctic falcon species of peregrine and gyrfalcon were considered further. Regarding the size, the recovered scapula conformed to that of both the male gyrfalcon and female peregrine falcon (Fig. 6, Table 1). Based on size alone, it is therefore not possible to reliably distinguish one species from another. The differences were, however, resolved by considering the dorsal view, which shows that the acromion differed in shape between the two falcon species. 


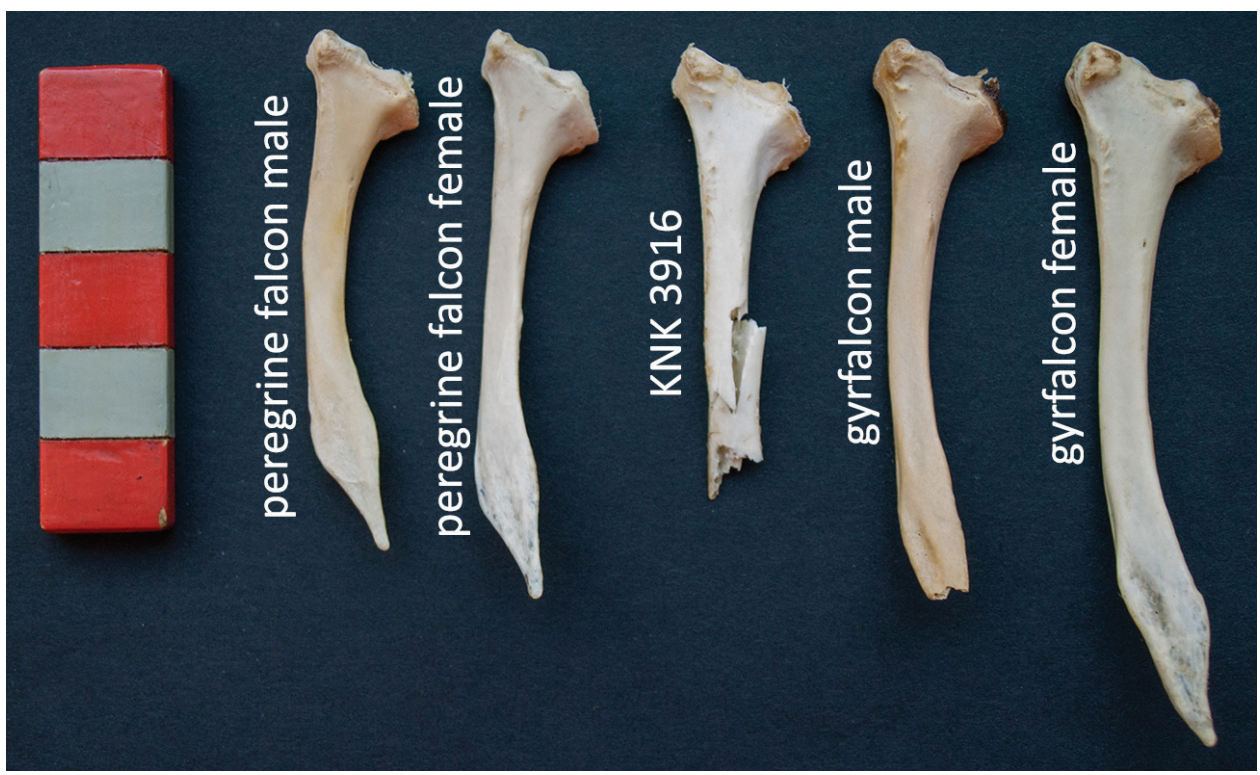

Fig. 6 Comparison of the scapula of cave specimen KNK 3916 with the scapulas of peregrine falcons and gyrfalcons.

Table 1 Comparison of greatest cranial diagonal (Dic) measurement on the scapula of the cave specimen (KNK 3916) versus those in the reference collection at the Natural History Museum of Denmark. Measurements were obtained using the procedure described by von den Driesch (1976). Those most similar to KNK 3916 are in boldface.

\begin{tabular}{llc}
\hline Catalogue number & Sex & Dic $(\mathrm{mm})$ \\
\hline KNK 3916 & & 16.44 \\
Falco rusticolus & & \\
A 277 & Female & 17.85 \\
A 785 & Female & 18.20 \\
AK 1160 & Female & 18.73 \\
AK 1300 & No information & 18.23 \\
A 278 & Male & $\mathbf{1 5 . 8 7}$ \\
AK 1043 & No information & 15.50 \\
Falco peregrinus & & \\
AK 1162 & Female & 17.05 \\
AK 1163 & Female & $\mathbf{1 6 . 3 0}$ \\
AK 1164 & Female & $\mathbf{1 5 . 8 6}$ \\
A 279 & Female & $\mathbf{1 5 . 8 7}$ \\
A 280 & Male & 14.53 \\
AK 1161 & Male & 14.16 \\
\hline
\end{tabular}

Specifically, for modern gyrfalcons and peregrine falcons of the same greatest cranial diagonal measurement, the gyrfalcon is more robust, with stronger muscle attachments, than the peregrine falcon. In this regard, KNK 3916 conforms to the gyrfalcon. Several lines of evidence including feather appearance, microscopic examination of barbs and the acromion shape of the scapula thus support the identification as a gyrfalcon.

\section{Radiocarbon age}

Radiocarbon dating of tissue (ETH-64502) found on the bone yielded a conventional ${ }^{14} \mathrm{C}$ age of $1184 \pm 26 \mathrm{yr}$ BP (Table 2). Following calibration using the IntCall 3 atmospheric curve (Ramsey \& Lee 2013; Reimer et al. 2013), a calendar age of 769-944 CE (1181-1006 yr BP) at the $95.4 \%$ confidence interval was obtained (Table 2, Fig. 7). A terrestrial-only radiocarbon curve is, however, unlikely to be suitable as Greenlandic gyrfalcons have been found to spend extended periods of time at sea (Burnham \& Newton 2011). In west Greenland, the summer diet of gyrfalcon comprises mostly of rock ptarmigan (Lagopus mutus) and Arctic hare (Lepus arcticus), with smaller quantities of passerines, waterfowl, Arctic fox pups (Alopex lagopus), shorebirds, gulls, alcids and falcons (Booms \& Fuller 2003). The exact proportion of terrestrial to marine-based food in the gyrfalcon diet is not known and changes depending on regional availability, migration routes and winter home-range (Nielson $\delta$ Cade 1990). Burnham \& Newton (2011) showed that falcons from the east coast of Greenland had an average winter home-range size of $48380 \mathrm{~km}^{2}$, compared to just $2595 \mathrm{~km}^{2}$ on the west coast. The east coast falcons therefore spent a much longer time at sea, far from land, in areas of sea ice or along the ice edge. Since the ratio of terrestrial to marine-based diet is not known, the conventional ${ }^{14} \mathrm{C}$ age has also been calibrated based on the Marine 13 model (Reimer et al. 2013) yielding a calendar age of 1182-1456 CE (768-494 yr BP) at the $95.4 \%$ confidence level (Fig. 8). 
Table 2 Radiocarbon date obtained on tissue remains of a gyrfalcon found in a cave in Kronprins Christian Land, north-east Greenland.

\begin{tabular}{lcccccc}
\hline Laboratory number & Material & Dry weight $(\mathrm{mg})$ & ${ }^{14} \mathrm{C}$ age $(\mathrm{a} \mathrm{BP}, 1 \sigma)$ & $\delta^{13} \mathrm{C} \%{ }^{\mathrm{a}}$ & $\begin{array}{c}\text { Calibrated }{ }^{14} \mathrm{C} \text { age } \\
(\text { cal yr CE) })^{\mathrm{b}}\end{array}$ & $\begin{array}{c}\text { Calibrated }{ }^{14} \mathrm{C} \text { age } \\
(\mathrm{cal} \text { yr CE) }\end{array}$ \\
\hline ETH-64502 & Tissue & 0.99 & $1184 \pm 26$ & $-21.1 \pm 1.0$ & $769-944$ & $1182-1456$ \\
\hline
\end{tabular}

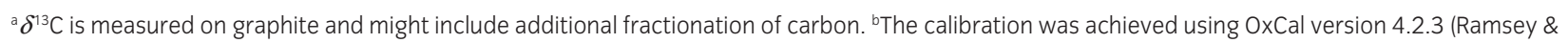
Lee 2013) and the IntCal13 atmospheric curve (Reimer et al. 2013). 'The calibration was achieved using OxCal version 4.2 .3 (Ramsey \& Lee 2013) and the Marine13 curve (Reimer et al. 2013). The marine reservoir correction is based on the weighted mean of the regional data from the marine database www.calib.org/marine (Håkansson 1975; Tauber \& Funder 1975; Funder 1982; McNeely et al. 2006). Weighted mean $\Delta R=131$. Standard deviation (square root of variance) $=81$.

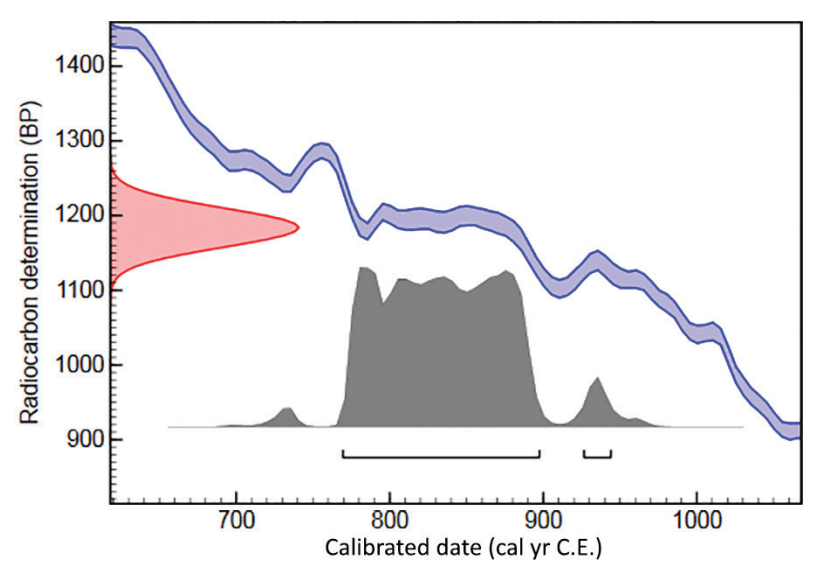

Fig. 7 Calibration of radiocarbon age $1184 \pm 26$ yr BP (left in red) on sample ETH-64502 at the 95.4\% confidence level using OxCal version 4.2 .3 (Ramsey \& Lee 2013) and the IntCal13 atmospheric curve (Reimer et al. 2013). The calibrated date is 769 to 944 cal yr CE (1181-1006 yr BP).

\section{Discussion}

The gyrfalcon is well-distributed throughout the circumpolar region, where it is known to nest on small ledges overhung by rock and in small caves (Burnham et al. 2009). The discovery of gyrfalcon remains in a cave in north-east Greenland is therefore not surprising. Caves used for breeding are often much smaller than the one discovered in this study; so, this location was more likely to have been a well-protected roosting location or may have been used for storage by a predator such as a fox. In the recent geological past, the bird had an even wider range of spread including most of southern Europe (Jánossy 1972; Mourer-Chauviré 1975). The earliest dated gyrfalcon (to our knowledge) was dated to ca. 11050 BCE (13000 yr BP) along the River Rhône between Geneva and Lyon (Debrosse 8 Mourer-Chauviré 1973, cited by Potapov \& Sale 2005, without calibration details). In North America, remains of the gyrfalcon were found in an archaeological site in Yukon that was dated to $2630 \mathrm{BCE}-1760 \mathrm{CE}$ (4580 to $190 \mathrm{yr} \mathrm{BP})$, though the

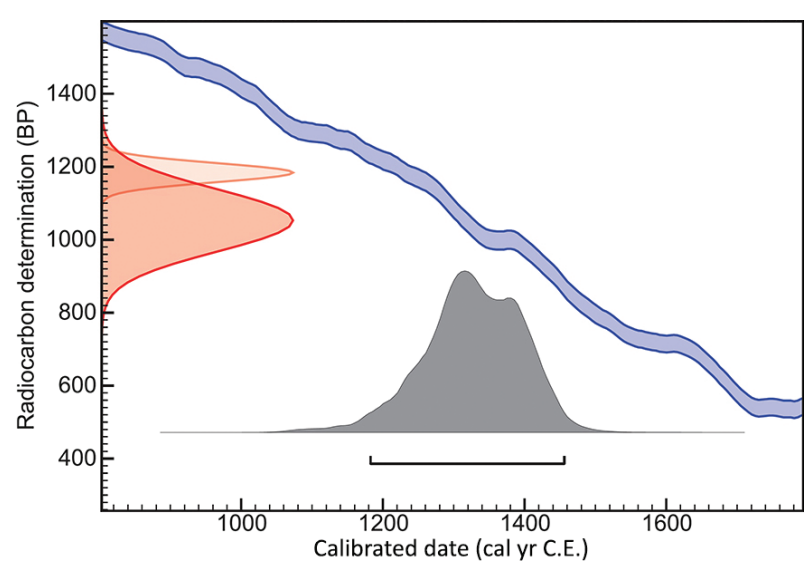

Fig. 8 Calibration of radiocarbon age $1184 \pm 26 \mathrm{yr}$ BP on sample ETH64502 at the $95.4 \%$ confidence level using OxCal version 4.2.3 (Ramsey \& Lee 2013) and 100\% Marine13 curve (Reimer et al. 2013). The marine calibrated date is 1182-1456 cal yr CE (768-494 yr BP).

gyrfalcon remains themselves were not dated and calibration details were not given (Dove et al. 2005). In Greenland, research into the continuous use of nesting sites over multiple generations yielded several dates for both guano and feathers between 950 CE (1000 yr BP) and 810-410 BCE (2760-2360 yr BP) (Burnham et al. 2009). These dates were all produced from the Kangerlussuaq area in central-west Greenland. Samples from Thule in north-west Greenland were either dated to ca. 1280-1400 CE (670-550 yr BP) or were outside the calibration range (Burnham et al. 2009).

Gyrfalcons are currently widespread throughout north-east Greenland (Boertmann 1994), but, to our knowledge, there is no record of gyrfalcons from this region before the modern era until the discovery presented here. Despite intensive archaeological activity in north Greenland between 1947 and 1995, no gyrfalcon remains were found among the hundreds of bird remains identified at the 137 explored sites $(51$ sites from ca. 2460-1860 BCE, 23 sites from ca. 900-400 BCE and 63 sites from ca. 1400 to 1500 CE; Grønnow \& Jensen 2003). 
Table 3 Gyrfalcon remains from archaeological sites in Greenland. Gyrfalcon remains reported by McGovern $(1985: 115,119)$ from $\vee 48$, analytical unit III, upper layers and V 54, room IV could not be found during re-examination of the bone material and were therefore omitted in the present survey.

\begin{tabular}{llllllll}
\hline Locality & Latitude & Longitude & Dating & Culture & Bones $(n)$ & Reference & Catalogue numbers $^{a}$ \\
\hline Nipisat I & 66.8146 & -53.4935 & Ca. 1310-810 BCE & Saqqaq Culture & 1 & Gotfredsen \& Møbjerg 2004 & Z.M.K. 136/1989 \\
Illorpaat & 64.1239 & -52.0840 & $1475-1700$ CE & Thule Culture & 1 & Møhl 1997 & Z.M.K. 142/1972 \\
V 51, Sandnes & 64.2440 & -50.1765 & $1025-1325$ CE & Norse & 4 & McGovern et al. 1996 & Z.M.K. 75/1981 \\
$\varnothing 17$ a, Narsaq & 60.9084 & -46.0388 & $1000-1500$ CE & Norse & 1 & McGovern et al. 1993 & Z.M.K. 104/1955 \\
Haabetz Colonie & 64.1355 & -52.0787 & $1721-1728$ CE & Colonial & 2 & Møhl 1979 & Z.M.K. 130/1970 \\
\hline
\end{tabular}

aZ.M.K numbers refer to catalogue numbers at the Natural History Museum of Denmark, where all bones are kept.

Elsewhere in Greenland, gyrfalcon remains from archaeological sites are scarce (Table 3). From among more than 60000 bird remains in a stratum dated to ca. 1310-810 $\mathrm{BCE}$, the oldest and hitherto northernmost record of the species is from Nipisat (Fig. 2) (and no bone was found in older strata dated 2020-1325 BCE [Gotfredsen \& Møbjerg 2004; C. Andreasen, pers. comm. 2019]). Notably, three out of five sites providing gyrfalcon bones were either Norse or Colonial, whereas numerous Inuit and pre-Inuit sites excavated over the last century are almost devoid of gyrfalcon remains, as seen in the case of Illorpaat (Fig. 2), in the Nuuk area, which produced one gyrfalcon bone out of 40000 alcid bones (Møhl 1997). This discrepancy may very well be due to cultural differences and not to climatically or environmentally driven forces.

Calibration of the conventional ${ }^{14} \mathrm{C}$ age using a $100 \%$ marine model has the effect of shifting the age to younger values (1182-1456 CE) as compared to the terrestrial-only calibration (769-944 CE). The true age is likely to be somewhere in between, as the gyrfalcon would be unlikely to have had a $100 \%$ terrestrial or $100 \%$ marine diet. Between 830 and $1100 \mathrm{CE}$ temperatures were generally elevated throughout the Northern Hemisphere above the late 20th century (1961-1990) baseline (Pages 2k Consortium 2013). This period of relative warmth, known as the MCA (Lamb 1965), extended in the Arctic to both earlier (ca. 600-760 CE; Patterson et al. 2010) and later dates (ca. 1300 CE; Patterson et al. 2010; Pages 2k Consortium 2013). Often it is considered that these warmer temperatures and a lack of sea ice enabled the settlement of Iceland (Lamb 1977, 1995) between 865 and 930 CE (Karlsson 2000).

Climate records for the MCA from north-east Greenland are sparse, and completely absent from the cave location. A 425-m long ice core drilled from the Flade Isblink ice cap $\left(81.2926^{\circ} \mathrm{N},-15.7029^{\circ} \mathrm{W}\right.$; Fig. 2; Lemark $2010), 150 \mathrm{~km}$ to the north-east, provides the closest palaeoclimate record during this time to our field site. Since the chronology of the record is preliminary, we do not put too much emphasis on the absolute timing, but rather note an increase in both the amount of melt and $\delta^{18} \mathrm{O}$ values between ca. 875 and 1200 CE (Lemark
2010), which would suggest that north-east Greenland also experienced elevated temperatures during the MCA. Interestingly, melting during the MCA appears to have been close to $100 \%$ and therefore much higher than the ca. $45 \%$ melting for the year $2000 \mathrm{CE}$. In comparison, $\delta^{18} \mathrm{O}$ values during the period of enhanced melting between 875 and $1200 \mathrm{CE}$ are more enriched at the start of this period compared to the year 2000 CE but drop to more depleted values from ca. 950 CE onwards.

With limited results and the discovery of only one gyrfalcon, which is a species that is known to migrate relatively long distances, detailed conclusions regarding either the climate or the historical breeding status of the species in this region are not possible at this stage. However, the situation of the partial decay of the body and its entombment within ice offers possibilities to understand the ice dynamics within the cave. Presumably, the bird did not inhabit the cave during a period when a thick wall of ice was present as it is today. The warmer temperatures of the MCA were therefore likely high enough to prevent extensive ice development within the cave. Following the death of the bird, the climate then cooled enough for ice to form in the cave, halting or reducing the speed of its decomposition. Such a hypothesis is supported by data from the Pages $2 \mathrm{k}$ Consortium (2013), which shows a general cooling in the Arctic from ca. 1200 CE to the end of the 19th century. Alternatively, warming of the karst rock above may have allowed water to infiltrate the subsurface and then freeze to ice, enclosing the bird. Both hypotheses require that the mean air temperature of the cave was below $0^{\circ} \mathrm{C}$ when the ice was formed. Under the current warming trend, the ice deposits within these caves and the preservation of the bird may be at risk. Loss of such potentially very valuable faunal materials seems to be an increasing trend from ice-preserved sites on a global scale (Rosvold 2018).

\section{Conclusion}

The documented presence of a gyrfalcon in the High-Arctic region of Kronprins Christian land, north-east 
Greenland, ca. 1000 years ago is, to our knowledge, the oldest and only pre-modern record of a gyrfalcon in the region. The age places the gyrfalcon in a time of elevated temperatures associated with the MCA. Furthermore, the entombment of the only partially decomposed remains within ice may have implications for understanding the ice dynamics within the cave.

\section{Acknowledgements}

The authors thank Chris Blakeley, Robbie Shone and Mark Wright for assistance in the field; Claus Andreasen for his help in listing previous archaeological records in the archives of the National Museum of Greenland; Clive Johnson, Jean-François Loubiere, Paul Smith, Cambridge Arctic Shelf Programme and the personnel at Mestersvig for providing logistical assistance.

\section{Funding}

This work was supported by funding from the Austrian Science Fund (project number T 710-NBL and Y 1162N37) to GEM, the Austrian Academy of Sciences General Science Fund to GEM and the French Polar Institute (Program 1036 Interactions) to OG. In addition, the fieldwork was funded by many other bodies, as listed in the supplementary information.

\section{Disclosure statement}

The authors report no conflict of interest.

\section{References}

Avibirds 2012. Falcons of the world. Accessed on the internet at https://avibirds.com/gyrfalcon/ on 28 April 2019.

Bennike O. \& Weidick A. 2001. Late Quaternary history around Nioghalvfjerdsfjorden and Jøkelbugten, northeast Greenland. Boreas 30, 205-227, doi: $10.1111 / \mathrm{j} .1502-$ 3885.2001.tb01223.x.

Bocheński Z. \& Tomek T. 2009. A key for the identification of domestic bird bones in Europe: preliminary determinations. Kraków: Institute of Systematics and Evolution of Animals, Polish Academy of Science.

Boertmann D. 1994. An annotated checklist to the birds of Greenland. Meddelelser om Gronland Bioscience 38. Copenhagen: University of Copenhagen.

Booms T.L. \& Fuller M.R. 2003. Gyrfalcon diet in central west Greenland during the nesting period. Condor 105, 528-537, doi: 10.1650/7147.
Brom T.G. 1986. Microscopic identification of feathers and feather fragments of Palearctic birds. Bijdragen tot de Dierkunde 56, 181-204, doi: 10.1163/ 26660644-05602001.

Burnham K.K. \& Burnham W.A. 2011. Ecology and biology of gyrfalcons in Greenland. In R.T. Watson et al. (eds.): Gyrfalcons and ptarmigan in a changing world. Pp. 1-20. Boise, ID: The Peregrine Fund.

Burnham K.K., Burnham W.A. \& Newton I. 2009. Gyrfalcon Falco rusticolus post-glacial colonization and extreme longterm use of nest-sites in Greenland. Ibis 151, 513-522, doi: 10.1111/j.1474-919X.2009.00939.x.

Burnham K.K. \& Newton I. 2011 . Seasonal movements of gyrfalcons Falco rusticolus include extensive periods at sea. Ibis 153, 468-484, doi: 10.1111/j.1474-919X.2011.01141.x.

Chandler A.C. 1916. A study of the structure of feathers, with reference to their taxonomic significance. University of California Publications in Zoology 13, 243-446, doi: 10.5962/ bhl.title.15062.

Debrosse R. \& Mourer-Chauviré C. 1973. Les oiseaux magdaléniens de Pierre-Châtel (Ain). (The Magdalenian birds of Pierre-Châtel.) Quartär 23-24, 149-164.

Dove C.J., Gregory Hare P. \& Heacker M. 2005. Identification of ancient feather fragments found in melting alpine ice patches in southern Yukon. Arctic 58, 38-43, doi: $10.14430 / \operatorname{arctic} 387$.

Dove C.J. \& Koch S.L. 2010. Microscopy of feathers: a practical guide for forensic feather identification. Journal of American Society of Trace Evidence Examiners 1, 15-61.

Funder S. 1982. ${ }^{14} \mathrm{C}$-dating of samples collected during the 1979 expedition to North Greenland. The Geological Survey of Greenland Report 110, 9-13.

Gotfredsen A.B. \& Møbjerg T. 2004. Nipisat-a Saqqaq culture site in Sisimiut, central west Greenland. Meddelelser om Grønland Man $\theta$ Society 31. Copenhagen: Danish Polar Center.

Grønnow B. \& Jensen J.F. 2003. The northernmost ruins of the globe. Eigil Knuth's archaeological investigations in Peary Land and adjacent areas of High Arctic Greenland. Meddelelser om Gronland Man e Society 29. Copenhagen: Danish Polar Center.

Håkansson S. 1973. University of Lund radiocarbon dates. VI. Radiocarbon 15, 493-513, doi: 10.1017/ S0033822200008961.

Hajdas I. 2008. The radiocarbon dating method and its applications in Quaternary studies. Quaternary Science Journal 57, 2-24, doi: 10.3285/eg.57.1-2.1.

Jánossy D. 1972. Die mittelpleistozäne Vogelfauna der Stánská Skálá. (The Middle Pleistocene bird fauna of Stánská Skálá.) Anthropos 20, 35-64.

Johnson J.A., Burnham K.K., Burnham W.A. \& Mindell D.P. 2007. Genetic structure among continental and island populations of gyrfalcons. Molecular Ecology 16, 3145-3160, doi: 10.1111/j.1365-294X.2007.03373.x.

Karlsson G. 2000. The history of Iceland. Minneapolis: University of Minnesota Press.

Krinsley D.B. 1960. Limnological investigations at Centrum Sø, northeast Greenland. Polarforschung 30, 24-32, doi: 10.2312/polarforschung.30.1-2.24. 
Lamb H.H. 1965. The early Medieval Warm Epoch and its sequel. Palaeogeography, Palaeoclimatology, Palaeoecology 1, 13-37, doi: 10.1016/0031-0182(65)90004-0.

Lamb H.H. 1977. Climate: Present, past and future. Vol. 2. Climatic history and the future. London: Methuen.

Lamb H.H. 1995. Climate, history, and the modern world. London: Routledge.

Lemark A. 2010. A study of the Flade Isblink ice cap using a simple ice flow model. MSc thesis, University of Copenhagen.

McGovern T.H. 1985. Contributions to the paleoeconomy of Norse Greenland. Acta Archaeologica 54, 73-122.

McGovern T.H., Amorosi T., Perdikaris S. \& Woollett J. 1996. Vertebrate zooarcheaeology of Sandnes V51: economic change at a chieftain's farm in west Greenland. Arctic Anthropology 33, 94-121.

McGovern T.H., Bigelow G.F., Amorosi T., Woollett J. \& Perdikaris S. 1993. The zooarchaeology of Ø 17a. In C.L. Vebæk (ed.): Narsaq-a Norse landnáma farm. Meddelelser om Gronland Man e Society 18. Pp. 58-74. Copenhagen: Danish Polar Center.

McNeely R., Dyke A.S. \& Southon J.R. 2006. Canadian marine reservoir ages, preliminary data assessment. Open File 5049. Ottawa: Geological Survey Canada.

Møhl J. 1979. The bones from Hope Colony. In H.C. Gulløv \& H.C. Kapel (eds.): Haabetz Colonie 1721-1728. Ethnohistorical studies of the meeting of Eskimo and European cultures. Ethnographical Series 16. Pp. 215-230. Copenhagen: National Museum of Denmark.

Møhl J. 1997. Faunal remains from Illorpaat. In H.C. Gulløv (ed.): From Middle Ages to colonial times-archaeological and ethnohistorical studies of the Thule culture in south west Greenland 1300-1800 AD. Meddelelser om Gronland Man $\theta$ Society 23. Pp. 495-501. Copenhagen: Danish Polar Center.

Mourer-Chauviré C. 1975. Les oiseaux du Pléistocène Moyen et Supérieur de France. (The Middle and Upper Pleistocene birds of France.) Documents des Laboratorie de Géologie de la Faculté des Sciences de Lyon 64. Lyon: Laboratory of Geology.

Nielson Ó.K. \& Cade T.J. 1990. Annual cycle of the gyrfalcon in Iceland. National Geographic Research 6, 41-62.

Otto C. 1981. Vergleichende morphologische Untersuchungen an Einzelknochen in Zentraleuropa vorkommender mittelgrosser Accipitridae. I. Schädel, Brustbein, Schultergürtel und Vorderextremität. (Comparative morphological studies of single bones of medium-sized Accipitridae in central Europe. I. Skull, breastbone, shoulder girdle and frontal limbs.) PhD thesis, University of Munich.
Pages 2k Consortium 2013. Continental-scale temperature variability during the past two millennia. Nature Geoscience 6, 339-346, doi: 10.1038/ngeol797.

Patterson W.P., Dietrich K.A., Holmden C. \& Andrews J.T. 2010. Two millennia of North Atlantic seasonality and implications for Norse colonies. Proceedings of the National Academy of Sciences of the United States of America 107, 5306-5310, doi: 10.1073/pnas.0902522107.

Potapov E. \& Sale R. 2005. The gyrfalcon. New Haven, CT: Yale University Press.

Ramsey C.B. \& Lee S. 2013. Recent and planned developments of the program OxCal. Radiocarbon 55, 720-730, doi: 10.1017/S0033822200057878.

Reimer P.J., Bard E., Bayliss A., Beck J.W., Blackwell P.G., Ramsey C.B., Buck C.E., Cheng H., Edwards R.L., Friedrich M., Grootes P.M., Guilderson T.P., Haflidason H., Hajdas I., Hatte C., Heaton T.J., Hoffmann D.L., Hogg A.G., Hughen K.A., Kaiser K.F., Kromer B., Manning S.W., Niu M., Reimer R.W., Richards D.A., Scott E.M., Southon J.R., Staff R.A., Turney C.S.M. \& van der Plicht J. 2013. Intcal13 and Marine13 Radiocarbon age calibration curves 0-50,000 years cal BP. Radiocarbon 55, 1869-1887, doi: 10.2458/azu_js_rc.55.16947.

Rosvold J. 2018. Faunal finds from alpine ice-Natural or archaeological depositions? Journal of Glacial Archaeology 3, 79-108. doi: 10.1558/jga.32414

Sokolov A.A., Fufachev I.A., Sokolov V.A., Sokolova N.A., Golovatin M.G. \& Dixon A. 2017. Gyrfalcons in a man-made landscape of the Yamal Peninsula (the Yamal-Nenets Autonomous District). Fauna of the Urals and Siberia 2, 180-185.

Stuiver M. \& Polach H.A. 1977. Discussion: reporting of ${ }^{14} \mathrm{C}$ data. Radiocarbon 19, 355-363, doi: 10.1017/ S0033822200003672.

Synal H.A., Stocker M. \& Suter M. 2007. MICADAS: a new compact radiocarbon AMS system. Nuclear Instruments and Methods in Physics Research Section B 259, 7-13, doi: 10.1016/j.nimb.2007.01.138.

Tauber H. \& Funder S. 1975. $\mathrm{C}^{14}$ content of recent molluscs from Scoresby Sund, central East Greenland. The Geological Survey of Greenland Report 75, 95-99.

von den Driesch A. 1976. A guide to the measurement of animal bones from archaeological sites. Peabody Museum Bulletin I. Cambridge, MA: Peabody Museum of Archaeology and Ethnology.

Wacker L., Nemec M. \& Bourquin J. 2010. A revolutionary graphitisation system: fully automated, compact and simple. Nuclear Instruments and Methods in Physics Research Section B 268, 931-934, doi: 10.1016/j.nimb.2009.10.067. 